\title{
Strong anion-exchange fast performance liquid chromatography as a versatile tool for preparation and purification of RNA produced by in vitro transcription
}

\author{
JIRI KOUBEK, ${ }^{1,2,3}$ KU FENG LIN, ${ }^{1,5}$ YET RAN CHEN, ${ }^{4}$ RICHARD PING CHENG, $^{2,6}$ and JOSEPH JEN TSE HUANG ${ }^{1,6}$ \\ ${ }^{1}$ Institute of Chemistry, Academia Sinica, Nankang, Taipei 11529, Taiwan \\ ${ }^{2}$ Department of Chemistry, National Taiwan University, Taipei 10617, Taiwan \\ ${ }^{3}$ Chemical Biology and Molecular Biophysics Program, Taiwan International Graduate Program, Academia Sinica, Nankang, Taipei 11529 , Taiwan \\ ${ }^{4}$ Agricultural Biotechnology Research Center, Academia Sinica, Nankang, Taipei 11529, Taiwan
}

\begin{abstract}
Here we demonstrate the use of strong anion-exchange fast performance liquid chromatography (FPLC) as a simple, fast, and robust method for RNA production by in vitro transcription. With this technique, we have purified different transcription templates from unreacted reagents in large quantities. The same buffer system could be used to readily remove nuclease contamination from the overexpressed pyrophosphatase, the important reagent for in vitro transcription. In addition, the method can be used to monitor in vitro transcription reactions to enable facile optimization of reaction conditions, and we have compared the separation performance between strong and weak anion-exchange FPLC for various transcribed RNAs, including the Diels-Alder ribozyme, the hammerhead ribozyme tRNA, and 4.5S RNA. The functionality of the purified tRNA ${ }^{\text {Cys }}$ has been confirmed by the aminoacylation assay. Only the purification by strong anion-exchange FPLC has led to the enrichment of the functional tRNA from run-off transcripts as revealed by both enzymatic and electrophoretic analysis.
\end{abstract}

Keywords: RNA purification; fast performance liquid chromatography (FPLC); in vitro transcription; strong anion exchange; tRNA

\section{INTRODUCTION}

Although the existence of RNA in cells has been well known, the discovery of catalytic RNA, RNA interference, long noncoding RNA, and the crystal structure of the ribosome have advanced the overall RNA paradigm recently. RNA was originally thought to be a scaffold molecule for proteins or a molecular intermediary for information transfer from DNA to proteins; however, current models show that RNA actively participates in the regulation of cellular processes (Cech and Bass 1986; Lilley 2003). RNA-related research usually requires pure RNA for structural and biochemical studies. For RNA generation, in vitro transcription is often the method of choice rather than overexpression, due to the difficulties in maintaining the stability of RNA produced within the cells, although protocols trying to overcome this issue have been developed with some success (Ponchon and Dardel 2011). Purification

\footnotetext{
${ }^{5}$ Present address: Division of Chemistry and Chemical Engineering, California Institute of Technology, Pasadena, CA 91125, USA

${ }^{6}$ Corresponding authors

E-mail jthuang@gate.sinica.edu.tw

E-mail rpcheng@ntu.edu.tw

Article published online ahead of print. Article and publication date are at http://www.rnajournal.org/cgi/doi/10.1261/rna.038117.113.
}

of the transcription products can be hazardous and tedious, and often requires multiple phenol:chloroform extractions and polyacrylamide gel electrophoresis (PAGE) (Hou and Schimmel 1988; Wyatt et al. 1991). Furthermore, ethanol-precipitated RNA can form aggregates (Uhlenbeck 1995) and is often contaminated with acrylamide oligomers (Lukavsky and Puglisi 2004).

Different chromatographic techniques have been used to purify cellular RNAs. In particular, anion-exchange chromatography has been reported in tRNA purification from total cellular RNA (von Ehrenstein 1967) and in the purification of overexpressed tRNA ${ }^{\text {Gln }}$ for crystallographic studies (Perona et al. 1988). With the advent of in vitro transcription and the emerging biological significance of short RNA molecules (<40 nt), high-performance liquid chromatography (HPLC) has been applied to purify short RNA transcripts for NMR structural studies (Anderson et al. 1996). The addition of the hammerhead ribozyme into the sequence has allowed workers to overcome the length limitation of short RNAs in HPLC purification (Shields et al. 1999).

Affinity purification using a tag attached to the $3^{\prime}$ end of the target RNA has been developed by Kieft and Batey (2004). The principle includes immobilization based on a protein-RNA 
interaction (between the signal recognition particle [SRP] RNA and the RNA-binding domain of the SRP protein from Tetrahymena thermophile) followed by cleavage with a cis-acting mutated ribozyme from the hepatitis delta virus. This method has been subsequently improved by replacing the protein-RNA interaction by the interaction between the Histagged maltose-binding protein-MS2 coat fusion protein (MBP-MS2) with the corresponding binding tag coupled to the $\operatorname{glm} S$ ribozyme, which is readily activated by glucosamine-6-phosphate (Batey and Kieft 2007; Keel et al. 2009). A similar technique has been reported recently, in which the glutathione-Sepharose interaction with glutathione-S-transferase fused with a $\lambda \mathrm{N}$ peptide has been exploited to bind BoxB RNA to bacteriophage $\lambda$ (Di Tomasso et al. 2011).

However, purification techniques that involve ribozyme cleavage (Price et al. 1995; Ferré-D’Amaré and Doudna 1996) are not always suitable. According to Sherlin et al. (2001), the attached ribozyme may form alternative structures with the desired RNA and thus disrupt the correct folding of the ribozyme, with its self-cleaving power disabled. A different approach with size exclusion chromatography to purify RNA transcripts has also been developed by Lukavsky and Puglisi (2004). This technique could remove unreacted nucleotides, enzymes, short abortive transcripts, oligomerimeric RNAs, RNA aggregates, and plasmids from the desired full-length monomeric transcript (McKenna et al. 2007). Finally, Easton et al. (2010) has also recently shown that RNA transcription reaction mixtures could be directly purified by weak anion-exchange FPLC to remove free nucleotides, short abortive transcripts, linearized plasmids, and enzymes from the desirable transcripts within $4 \mathrm{~h}$.

While cotranslational protein-folding studies and nascent chain fluorescent labeling are the main focus in our laboratory, we are interested in the production of engineered tRNA ${ }^{\mathrm{Cys}}$, which is a critical material in generating fluorescent macromolecules. In this study, we show the generality of using strong anion-exchange (Mono Q) FPLC for transcript purification and in the studies of transcription reactions. Short linear templates as well as nuclease-free pyrophosphatase, an important enzyme used for in vitro transcription (Rupert and Ferré-D'Amaré 2004), have been obtained/purified in high yields. The applicability of FPLC as an alternative tool to conventional PAGE to follow transcription reactions is demonstrated here. By directly applying the transcription reaction mixture on to the column, unreacted rNTPs (offering the possibility of recycling), short abortive transcripts, and the desired transcript can be readily separated from the template DNA. We have successfully applied this method to a variety of RNAs with different chain lengths, including tRNA ${ }^{\text {Cys }}$, ribozyme transcripts, and 4.5S RNA transcripts. The enrichment of biofunctional transcripts has also been accomplished due to its high separating power as confirmed by the aminoacylation assay. Finally, as part of the study, we have compared the performance of this method with that of weak anionexchage FPLC.

\section{RESULTS AND DISCUSSION}

\section{Preparation of nuclease-free pyrophosphatase}

The preparation of enzymes is routine for large-scale reactions. Typical enzymes for RNA research include T7 RNA polymerase (He et al. 1997) and aminoacylases (RodríguezHernández and Perona 2011). Pyrophosphatase is an important enzyme for in vitro transcription (Rupert and FerréD'Amaré 2004; Easton et al. 2010) and aminoacylation (Lin et al. 2012). Although pyrophosphatase is commercially available, this enzyme can be readily prepared in two steps. Nickel affinity purification can be used after attaching a Histag to the $\mathrm{C}$ terminus. Unfortunately, nuclease impurities are still present, because DNA and RNA are continually being degraded after $12 \mathrm{~h}$ of incubation with pyrophosphatase (Fig. 1A,B). Moreover, subsequent purification with strong anion-exchange Mono Q FPLC yields many peaks (Fig. 1C), as evidenced by the UV absorbance at $280 \mathrm{~nm}$. The functional pyrophosphatase has a hexameric structure, and the multiple species arise from various association states of the enzyme in solution. Since the contaminating nucleases may exist only in trace amounts hidden below the signal of pyrophosphatase, we have tested each fraction for DNase contamination (Fig. 1D). The fractions considered free of DNase according to this analysis are then evaluated for RNase activity (Fig. 1E). The combined fractions eluted at higher ionic strengths show negligible nuclease activities (Lane B in Fig. 1F,G).

The specific activity for the combined fractions with no detectable nuclease contamination has been evaluated by the malachite green assay as 5 units/ $\mu \mathrm{L}$. The total enzyme yield from a single 200-mL culture overexpression exceeded 5000 units. Thus, this procedure can provide ample amounts of nuclease-free pyrophosphatase suitable for large-scale RNA preparations, where cost is a serious issue (McKenna et al. 2007).

\section{Preparation of transcription templates}

One of the key aspects of transcription reactions is the quality and quantity of the template. Linearized plasmids are a common choice for the ease of amplification and quality control (Hou et al. 1993; Kim et al. 2007; Keel et al. 2009; Pikovskaya et al. 2009; Di Tomasso et al. 2011). Other linear templates such as PCR reaction products or DNA synthesized by refilling of overhanging nucleotides by DNA polymerase I (Sherlin et al. 2001) are sometimes preferred because such templates can contain modified nucleotides (Kao et al. 1999).

Typical procedures for the purification of short linear templates involve purification kits or precipitation of nucleic acids in ethanol. However, usual purification kits are generally limited by the base-pair cutoff (usually 70-100 bp, depending on the manufacturer) and relatively low binding capacity (usually 10-20 $\mu \mathrm{g}$ of DNA). On the other hand, ethanol precipitation may precipitate unreacted primers and fragments 

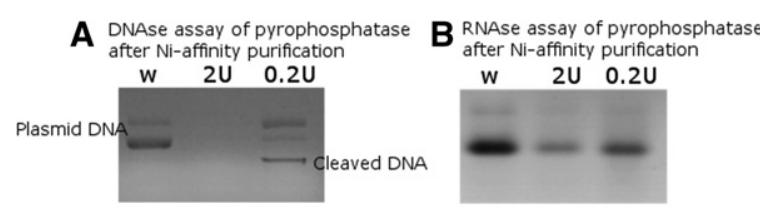

C Chromatogram of pyrophosphatase applied on Mono Q column

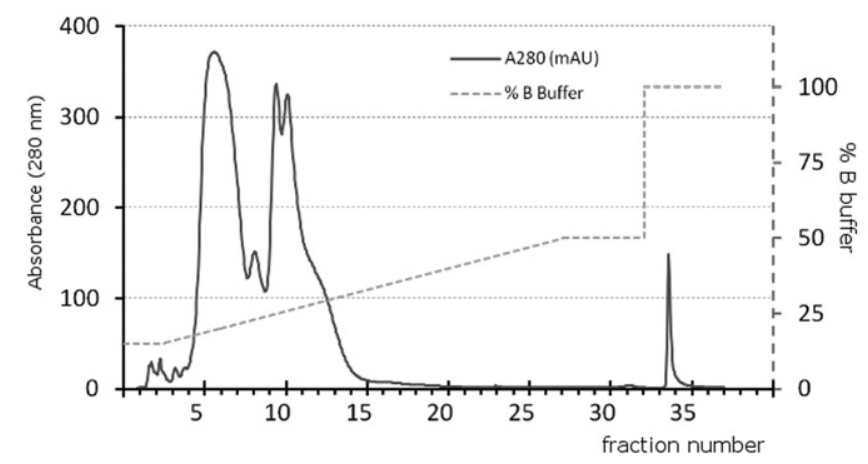

D

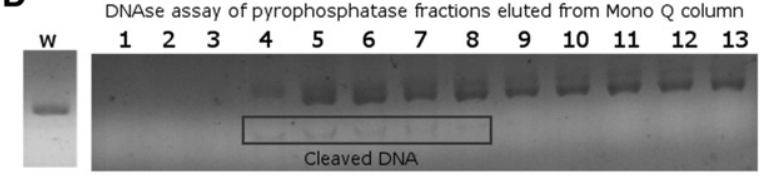

E RNAse assay of pyrophosphatase fractions eluted from Mono Q column

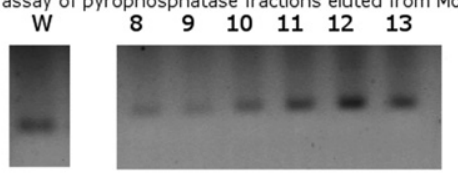

$\mathbf{F}$

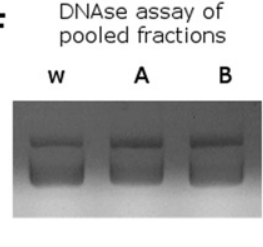

G RNAse assay of pooled fractions W A B

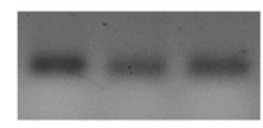

FIGURE 1. Applying Mono Q column for obtaining nuclease-free pyrophosphatase. Incubation of 2 and 0.2 units of pyrophosphatase purified on a nickel affinity column with plasmid DNA $(A)$ and small RNA $(B)$ for $>12 \mathrm{~h}$ compared with the control incubated with water $(\mathrm{w})$. ( $C)$ The chromatogram of the pyrophosphatase purification on the Mono Q column after the nickel affinity column. The pyrophosphatase is eluted in a broad range of fractions, possibly caused by oligomerization of the enzyme. $(D)$ Testing of the fractions 1-13 for DNase activity. Some fractions (1-4) show full degradation of the plasmid DNA, while others (5-7) indicate endonuclease cleavage. $(E)$ RNase assay of the fractions 8-13. While the fractions 8 and 9 show signs of a minor RNase contamination, the fractions 10-13 appear to be clear of any RNase contamination. The fractions 8 with $9(A)$ and $10-13$ $(B)$ are pooled for confirming DNase $(F)$ and RNase active impurities $(G)$.

formed in the reaction. This may interfere with the following transcription reaction(s), especially if the nucleotide with the strong promoter can form a hairpin at the $3^{\prime}$ end to potentially serve as a polymerase primer for making dsDNA.

Our initial attempts to produce transcription templates using oligonucleotide extension with Klenow fragments involve purification using a commercial purification kit, which leads to a pure template (Fig. 2A). However, yields do not exceed 6 $\mu \mathrm{g}$ per column. As such, the purification is performed using the Mono $Q$ column. First, we determine the optimal reaction conditions by altering the cycle length and the number of cycles (Fig. 2B-E). The desired dsDNA product is expected to bind the column tightly and require high ionic strength for elution. Fifty-five-nucleotide ssDNA reagents are expected to be eluted by lower ionic strengths. With the optimized temperature program (Fig. 2E), the reaction volume is scaled up to $500 \mu \mathrm{L}$. Importantly, Mono Q FPLC could purify $100 \mathrm{bp}$ of DNA from $~ 55$-base nucleotides and unreacted dNTPs (Fig. 2F).

The fractions 8 with 9 and 10 with 11 (Fig. 2 F) are separately combined, precipitated, and redissolved in $40 \mu \mathrm{L}$ of TE buffer, and analyzed with agarose electrophoresis. The combined fractions 10 with 11 contain the desired product, whereas the combined fractions 8 with 9 contain mostly the unreacted oligonucleotides (Fig. 2G). According to the UV absorbance at $260 \mathrm{~nm}$, the concentration of the combined fractions 8 with 9 is $250 \mathrm{ng} / \mu \mathrm{L}$, and the concentration of the combined fractions 10 with 11 is $1350 \mathrm{ng} / \mu \mathrm{L}$. The total yield of the purified DNA template exceeds $50 \mu \mathrm{g}$.

\section{Monitoring RNA transcription optimization}

High yields of RNA transcripts often require optimization for each reaction (e.g., concentration of $\mathrm{Mg}^{2+}$, rNTPs, template). To optimize RNA production, a procedure for facile screening of transcription conditions has been developed. To determine the sensitivity of this method, several dilutions of our stock RNA transcript mixed each with 500 pmol of (TG) 6 oligonucleotide are prepared. The sample is applied on to the strong anion-exchange Mono Q column preequilibrated in $20 \mathrm{mM}$ HEPES and $0.32 \mathrm{M} \mathrm{NaCl}(\mathrm{pH} 7.5)$, and the sample is eluted by a linear gradient of the B buffer. We find that $78 \mathrm{ng}$ of RNA could not be distinguished from the background noise, whereas $275 \mathrm{ng}$ of RNA is above the limit of detection (Fig. $3 \mathrm{~A})$. The signal is linearly proportional to the amount of RNA applied to the column $\left(R^{2}=0.99\right)$ (Fig. 3B), suggesting that Mono Q FPLC is a suitable alternative to determine RNA transcription conditions accurately. Accordingly, we have used the strong anion-exchange Mono Q FPLC to evaluate the RNA produced by in vitro transcription under different conditions.

Several variables are tested including concentration of rNTPs, $\mathrm{MgCl}_{2}$, dithiotreitol (DTT), pyrophosphatase, and single-strand binding protein (SSB). It is apparent that the concentration of $\mathrm{MgCl}_{2}$ and rNTPs (Fig. 3C,D) has more influence on the transcription yield compared with the other components, which is consistent with previously published reports (Sherlin et al. 2001; McKenna et al. 2007; Easton et al. 2010). Importantly, the need to optimize each batch of 
A
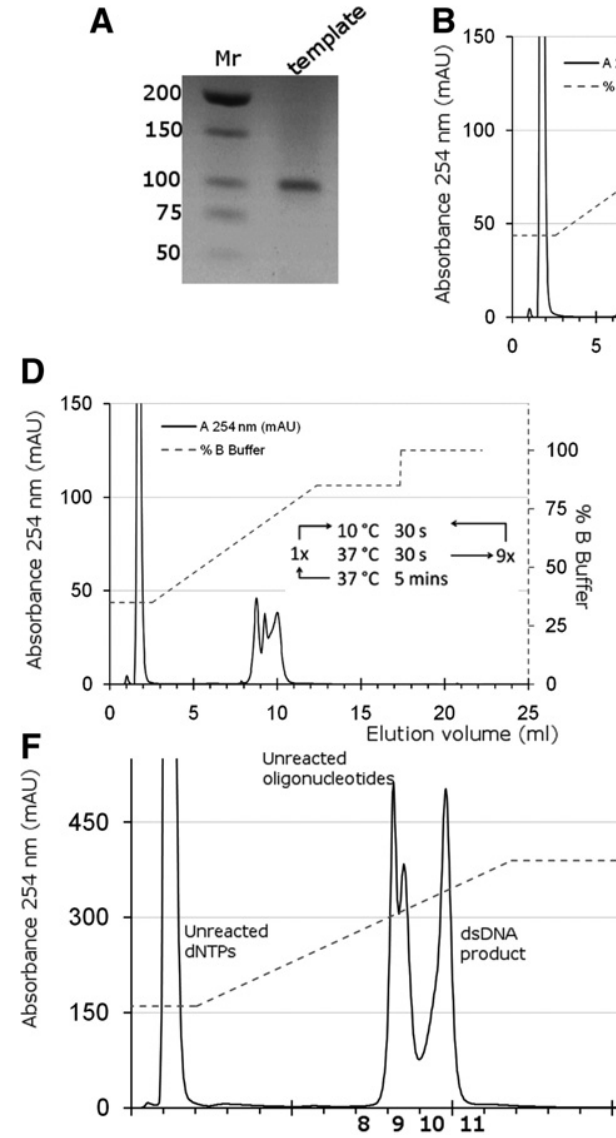
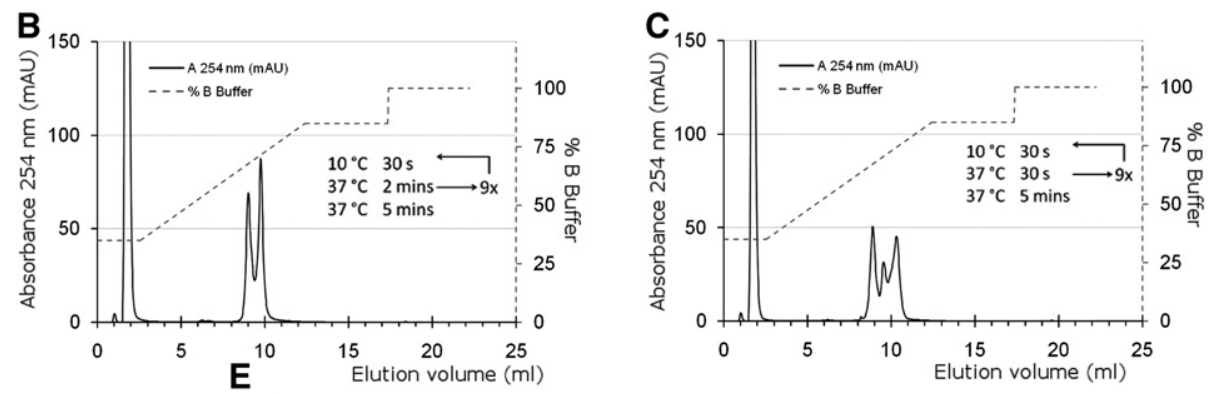
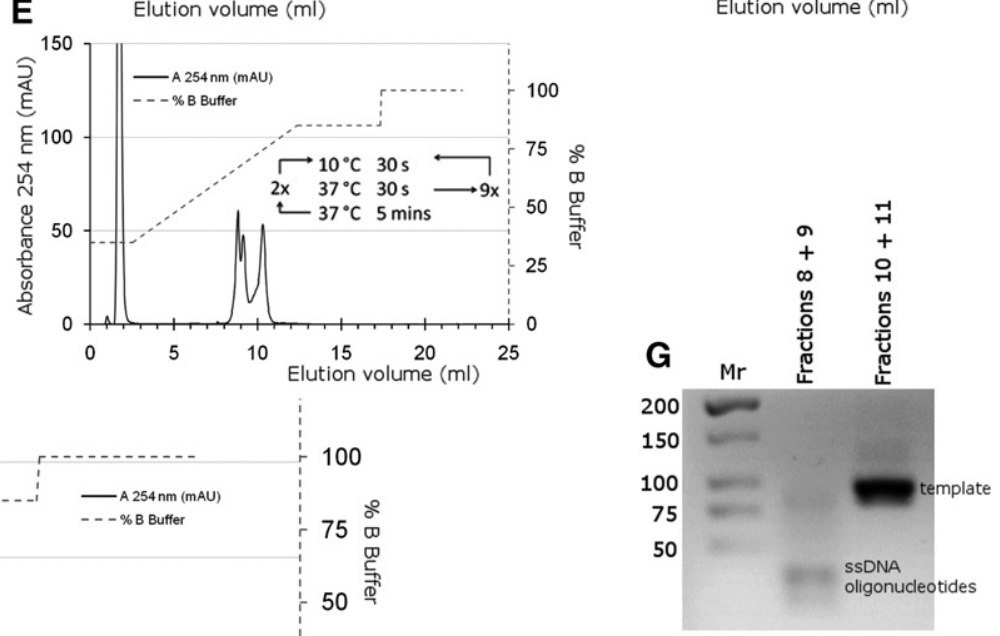

FIGURE 2. Transcription template preparation and purification. (A) A 100- $\mu \mathrm{L}$ reaction is purified using a PCR purification kit and eluted into $30 \mu \mathrm{L}$ of which $2 \mu \mathrm{L}$ is loaded on a $3 \%$ agarose gel. $(B-E)$ The comparison of different temperature programs in $50 \mu \mathrm{L}$ of reaction volume. $(F)$ Five-hundredmicroliter reaction with the temperature program in $E$. The fractions 8 with 9 and 10 with 11 are combined and precipitated with ethanol. $(G)$ Agarose electrophoresis of the precipitated fractions; each well is loaded with $0.5 \mu \mathrm{L}$ of the precipitated and redissolved sample; the fractions 8 with 9 contain unreacted oligonucleotides, and the fractions 10 with 11 contain mostly full-length product.

reagents (McKenna et al. 2007) makes strong anion-exchange FPLC an alternative to standard screening procedures. A typical screening is performed in 20-25 $\mu \mathrm{L}$ (Easton et al. 2010), which is sufficient and convenient for the Mono Q FPLC system.

The performance of FPLC analysis makes it a compelling method for cases in which only a limited number of conditions are screened if time is a major concern. With larger amounts of screening reactions, electrophoresis is less time demanding because it allows multiple sample analysis. Nevertheless, an additional advantage of FPLC in the screening is that it circumvents the use of potentially hazardous chemicals that are typically employed for polyacrylamide gel preparation and nucleic acid staining. The digital output of the UV absorption signal is also more convenient for data quantification. In the end, the PAGE analysis should still be the preferred method for setting up a new transcription reaction when multiple variables must be adjusted to optimize the reaction conditions. However, the advantages of the FPLC analysis are apparent for routine checks of reagent batches (such as the template or the polymerase).

\section{Purification of transcription products including tRNA, ribozyme, and 4.5S RNA transcripts}

To purify the desired RNA transcripts from unreacted rNTPs, DNA template, and abortive short fragments, we have also resorted to strong anion-exchange Mono Q FPLC. When a steep elution gradient of the B buffer is applied to the FPLC column (increment of $50 \mathrm{mM} \mathrm{NaCl}$ per column volume [CV]), numerous peaks with absorbance at $254 \mathrm{~nm}$ are observed (Fig. $4 \mathrm{~A})$. Some of these peaks correspond to free nucleotides and others are short abortive transcripts. Importantly, the desired 74-nt-long RNA transcript ( $\mathrm{tRNA}^{\mathrm{Cys}}$ ) is fully separated from the free nucleotides and the short abortive transcripts, although still not fully separated from the template peak.

When a shallower gradient is applied $(25 \mathrm{mM} \mathrm{NaCl}$ per $\mathrm{CV})$ to the column preequilibrated with $20 \mathrm{mM}$ HEPES, $0.32 \mathrm{M} \mathrm{NaCl}, \mathrm{pH} 7.5$ (30\% B buffer), free nucleotides are eluted in the void volume, and the separation of the desired tRNA transcript from the remaining template was greatly improved (Fig. 4B). The remaining template could be recycled as described for linearized plasmids (Jahn et al. 1991). We 
A

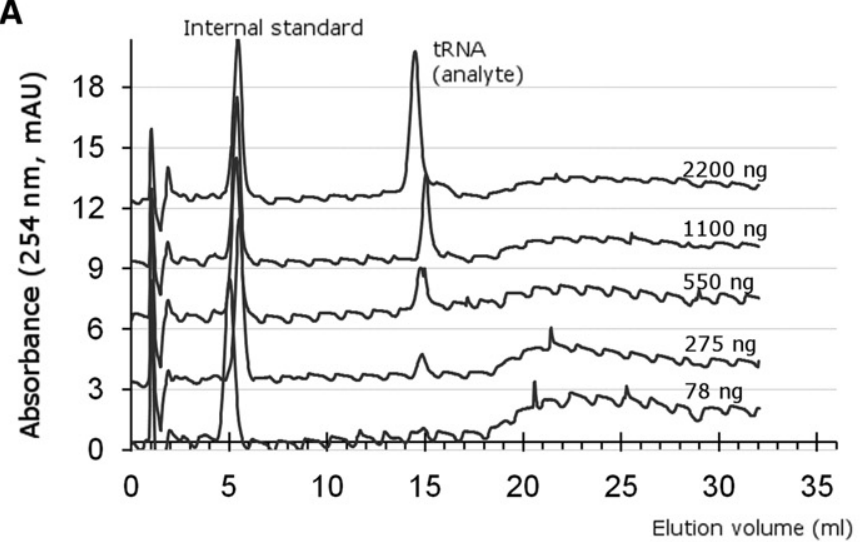

C

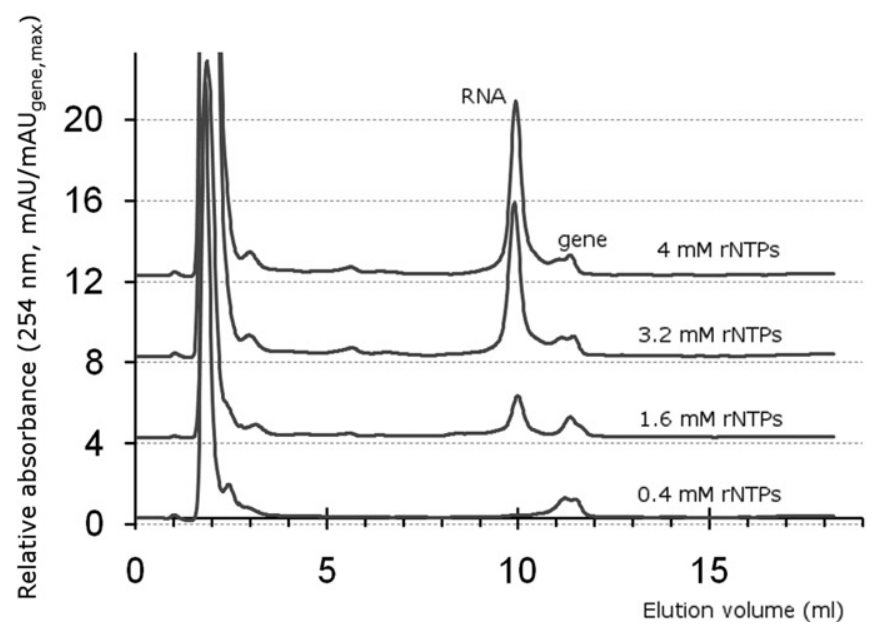

B

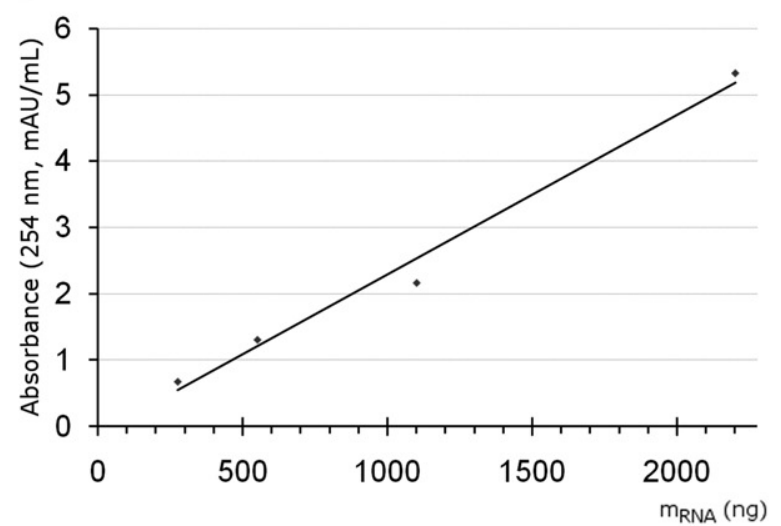

D

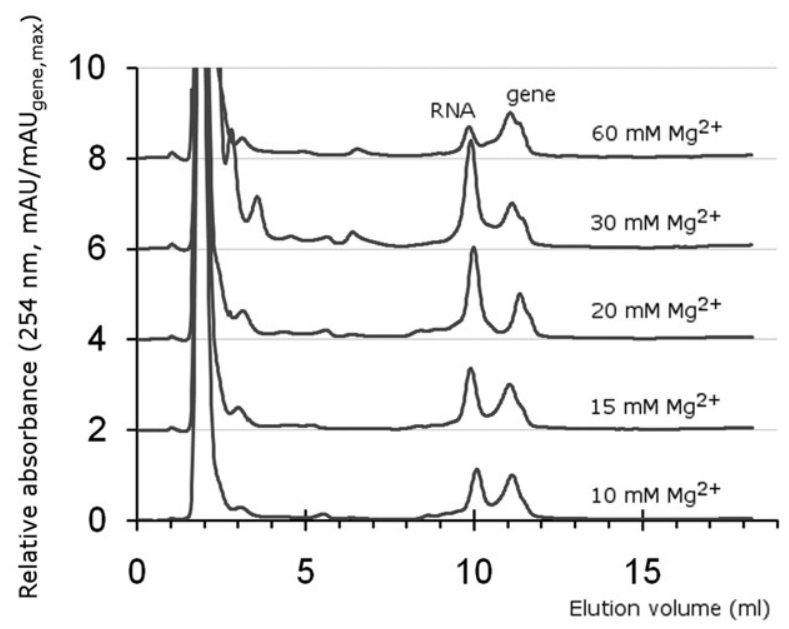

FIGURE 3. Monitoring the transcription conditions by strong anion-exchange FPLC. (A) To establish the minimum RNA amount that should be presented in the transcript, various RNA amounts $(78,275,550,1100$, and $2200 \mathrm{ng})$ are applied onto the column and eluted to obtain the instrument response. The 275-ng amount is clearly distinguishable from the background (signal $=1.2 \mathrm{mAU}$, noise standard deviation $0.1 \mathrm{mAU}$ ). (B) The instrument response is evaluated as linear. $(C)$ The transcription conditions are tested for different concentrations of rNTPs and are standardized based on the template peak. The template and transcript peaks are identified by incubating one transcription reaction with 100 mM EDTA (data not shown). (D) The influence of $\mathrm{Mg}^{2+}$ concentration on the transcription.

believe that the non-Gaussian distribution of the transcript peak is caused by the presence of runoff transcripts in the product. The identity of the transcript is confirmed by denaturing acetate-urea PAGE based on its size (Fig. 4C), and by an aminoacylation assay that shows an acceptor activity of the eluted RNA for cysteine in the presence of ATP and cysteinyltRNA-synthetase measured as ${ }^{35} \mathrm{~S}$-cysteine containing trichloroacetic acid (TCA) precipitates retained on the 3MM filter. We confirm the identity of the fraction $17 \mathrm{~b}$ as the template DNA by the TBE agarose gel electrophoresis after incubation with DNase I (Fig. 4D).

To further test the ability of the strong anion-exchange column in separating the runoff transcripts from the active product, two different templates are transcribed; one contains $2^{\prime}$-O-methyl-nucleotides at the $5^{\prime}$ end of the complementary strand (Fig. 4E) and the other encoding for only standard 2'-deoxynucleotides (Fig. 4F). An unmodified template is known to produce high amounts of the runoff tran- scripts, while $2^{\prime}-O$-methylation of the last two nucleotides in the template can significantly reduce the 3'-RNA heterogeneity (Kao et al. 1999; Sherlin et al. 2001). Surprisingly, the difference between transcripts of the template containing $2^{\prime}$ $O$-methyl nucleotides and transcripts of the template containing $2^{\prime}$-deoxynucleotides turns out to be remarkable, because we have expected only minor differences in the shapes of the eluted transcript peaks. Each fraction of the RNA transcribed from the template without modification (Fig. $4 \mathrm{~F}$ ) is tested for the cysteine acceptor activity. The fractions $13 \mathrm{f}$ and $14 \mathrm{f}$ show twofold to threefold higher cysteine acceptor activity per absorbance unit at $260 \mathrm{~nm}$ than the fractions $12 \mathrm{f}$ and $15 \mathrm{f}$. This result is consistent with the distribution of the major peak in Figure 4E, which is obtained by the transcription of the template with the modified nucleotides to reduce the runoff transcripts. The overlay of the two chromatograms is depicted in Figure 4G. To compare this method with weak anion-exchange chromatography, we have purified 

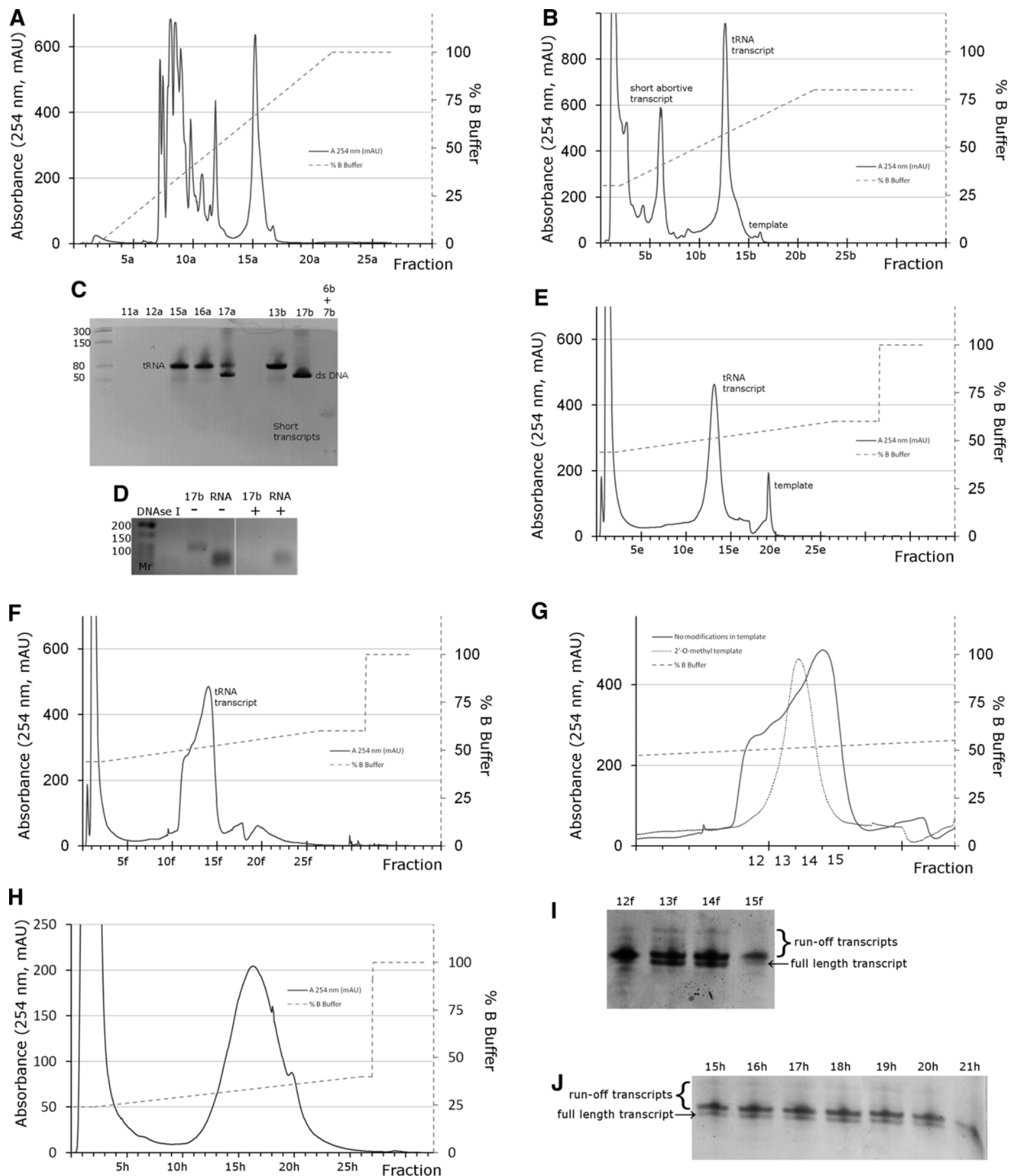

FIGURE 4. Purification of the transcription reaction and the impact of different gradient slopes on observed peaks. $(A)$ Different nucleotides can be distinguished from each other if eluted with a steep gradient starting at $20 \mathrm{mM} \mathrm{NaCl}$ concentration. (B) Starting at 30\% B Buffer allows better separation of the transcription products, including full separation of the transcribed tRNA (fractions $13 \mathrm{~b}$ and $14 \mathrm{~b}$ ) from the short template (Fraction 17b). (C) Visualization of the collected fractions from $A$ and $B$ on $15 \%$ NaOAc polyacrylamide gel (pH 5.0) with SybrGreen. While the fractions $9 \mathrm{a}$ and $10 \mathrm{a}$ cannot be visualized on gel, the pooled fractions $6 \mathrm{~b}$ and $7 \mathrm{~b}$ clearly show to contain short abortive transcripts (bands below 50 -nt marker). (D) The identity of the fraction $17 \mathrm{~b}$ is confirmed on a $2 \%$ agarose gel. Incubation of small RNAs is done in the same manner to highlight the difference. (E) A shallow gradient elution profile of the reaction transcribed from the modified template $\left(2^{\prime}-O\right.$-methyl modifications on the $5^{\prime}$ end of the complementary strand) and $(F)$ from the template without the modifications. The fractions $12 \mathrm{f}, 13 \mathrm{f}$, $14 \mathrm{f}$, and $15 \mathrm{f}$ are collected, precipitated, and, after refolding, their aminoacylation yield is measured. The aminoacylation yield distribution is similar to $G$, which is the overlay of $E$ and $F$ chromatograms with the maximum in the fractions 13 and 14. $(H)$ The tRNA transcription reaction from the template without the modified nucleotides purified on DEAE Sepharose shows a Gaussian peak distribution. The analysis on 12\% TBE-urea PAGE revealed (I) an accumulation of the full-length transcript when the reaction is purified on the Mono Q column $(J)$, but this accumulation is not observed in the fractions collected from the DEAE-Sepharosepurified transcript. 
the transcription reaction using the unmodified template on DEAE Sepharose (Fig. 4H). Denaturing electrophoresis of the Mono Q-purified transcription reaction shows intensive bands of the full-length transcript in the fractions $13 \mathrm{f}$ and $14 \mathrm{f}$, while a lower content of the full-length transcript could be observed in the fractions $12 \mathrm{f}$ and $15 \mathrm{f}$ (Fig. 4I). The fractions obtained from DEAE Sepharose do not show any enrichment of the full-length transcript, as judged by the band intensity on the denaturing electrophoresis (Fig. 4J).

Although full separation of the transcription products from the runoff transcripts remains difficult, the enrichment of the transcript with acceptor activity offers promise for further development of the strong-anion exchange resin for the chromatographic separation of transcription products. Flanagan et al. (2003) have mentioned that strong anion-exchange chromatography allows certain separation of the acceptor active tRNA transcripts from the inactive transcripts; however, no details have been published. Similarly, Gubbens et al. (2010) have measured the acceptor activity of wild-type (WT) tRNA ${ }^{\text {Cys }}$, produced from linearized plasmids and purified on the Mono Q column, to be 480 pmol per unit of absorbance at $260 \mathrm{~nm}$ corresponding to $\sim 30 \%$ of the theoretical aminoacylation yield. Our aminoacylation yields for tRNA $^{\text {Cys }}$ after refolding are mostly between $25 \%$ and $35 \%$ for $\mathrm{tRNA}^{\mathrm{Cys}}$ derived from Escherichia coli (non-refolded tRNA could be aminoacylated up to $15 \%$ of the theoretical yield) and up to $25 \%$ for tRNA ${ }^{\text {Cys }}$ derived from Bacillus subtilis. A typical aminoacylation yields for tRNA ${ }^{\text {Cys }}$ from E. coli transcribed using the $2^{\prime}$ - $O$-methyl-modified template and purified by PAGE are $60 \%-70 \%$ (Hauenstein et al. 2004).

To further characterize the differences between strong anion-exchange chromatography (Mono Q) and weak anionexchange chromatography (DEAE Sepharose), we have transcribed several other RNAs, with different lengths and conformations including the Diels-Alder ribozyme (Seelig and Jäschke 1999), the hammerhead ribozyme (Avis et al. 2012), and 4.5S RNA (Gu et al. 2005). Each transcription reaction $(600 \mu \mathrm{L})$ has been divided into two aliquots and purified on Mono Q or DEAE Sepharose; the collected fractions are pooled and analyzed on denaturing acetate-urea PAGE (Fig. 5).

In general, all transcripts have been eluted under similar conditions. For the strong anion-exchange column, a gradient from 0.46 to $0.62 \mathrm{M} \mathrm{NaCl}$ over $25 \mathrm{CV}$ is used; the weak anion-exchange column requires a gradient from 0.26 to $0.42 \mathrm{M} \mathrm{NaCl}$ over $25 \mathrm{CV}$. In the case of the Diels-Alder ribozyme transcript (28 nt) (Fig. 5A-C) and the tRNA transcript (74 nt) (Fig. 5G-I), purification by the Mono Q column and DEAE Sepharose yields a single transcription product. In the transcription reactions with multiple detectable bands on denaturing PAGE (Fig. 5D-F and J-L), the desirable product is identified by its size on the gel. The DNA band has been identified by incubation with RNase A (data not shown). One additional RNA product is also observed in the hammerhead ribozyme transcription reaction (Fig. 5D-F).
Easton et al. (2010) have promoted DEAE Sepharose as a rapid nondenaturing purification method for the purification of properly folded RNA transcripts. Our aminoacylation data on tRNA acceptor activity suggest that purification on a strong anion-exchange column may interfere with the RNA conformation, possibly due to the higher ionic strength required for the transcript elution. Unlike size exclusion chromatography (Lukavsky and Puglisi 2004; McKenna et al. 2007), both weak and strong anion-exchange chromatography avoid phenol: chloroform extraction as well as desalting after in vitro transcription, thus minimizing the need for the sample manipulation prior to the purification. The separation of RNA on size exclusion chromatography is highly dependent on the overall transcript size and shape. McKenna et al. (2007) have found that stem-loop RNA molecules behave like proteins of fourfold to sixfold sizes. Another limitation of gel filtration chromatography is the sample loading, because there is a maximum volume of the sample that can be loaded if ideal performance is to be achieved. Anion-exchange chromatography is limited only by the ability of the column to bind a sample, regardless of the volume load. Weak anion-exchange chromatography has been reported to be suitable for purification of transcripts 30-500 nt long (Easton et al. 2010) when the method can efficiently separate RNA products from short abortive transcripts and linearized plasmid templates. Our study has shown that DEAE Sepharose may not be a suitable method when short dsDNA (e.g., PCR product) is used as a template since they tend to be coeluted with the main transcript fractions (Fig. 5F,L).

To achieve full RNA recovery, Mono Q FPLC has been reported to require multiple elutions (Pikovskaya et al. 2009). This is not observed in the present study, but the outcome could be highly dependent on the overall RNA structure and the amount loaded. Most importantly, the resolution of the Mono Q column is superior to the resolution of DEAE Sepharose, which is also noted in a comparison of the strong and weak anion-exchange monolithic columns (Romanovskaya et al. 2013). The elution profiles of the Mono Q-eluted transcripts exhibit generally a smaller peak width, while the transcripts from DEAE Sepharose are usually eluted as a broad peak mixed with the template DNA. The higher resolving power of the strong anion-exchange column is clearly evident by standard chromatographic characteristics (peak width) as well as by the aminoacylation assay that shows the enhancement of the full-length transcript.

Overall, strong anion-exchange FPLC is a powerful and universal tool in the RNA production via in vitro transcription. It can be used for the preparation of enzymes and templates as well as in routine monitoring of the transcription reaction. We have also demonstrated how the strong anionexchange FPLC could be used to purify tRNA transcripts from unreacted nucleotides, templates, and short abortive transcripts. Importantly, fractions with a higher aminoacylation activity are obtained, suggesting good separation of the full-length RNA product from heterogeneous transcripts. 
A

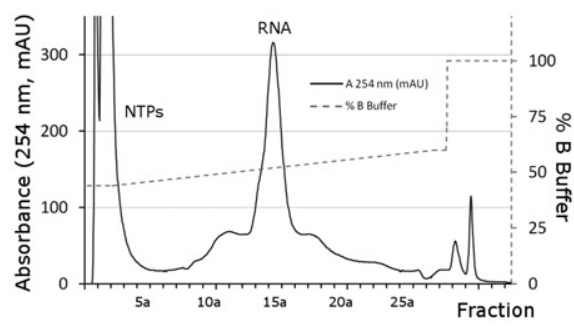

D

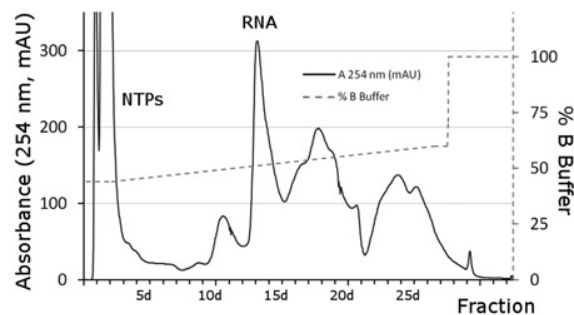

G
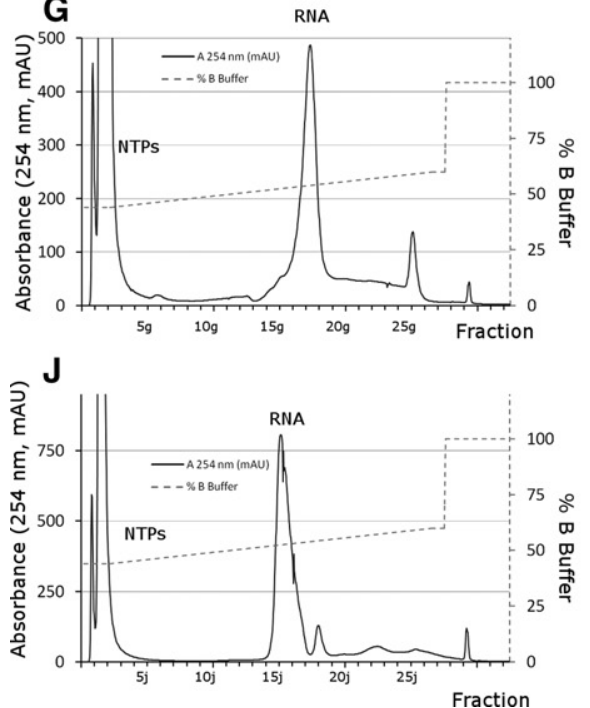

B

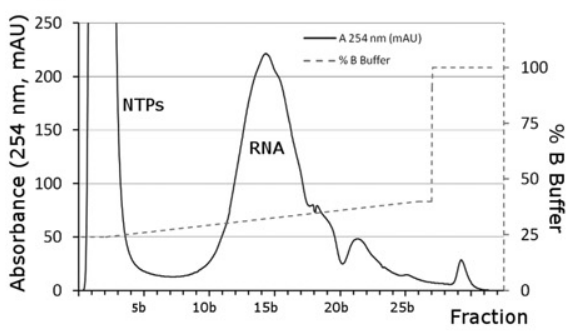

$\mathbf{E}$

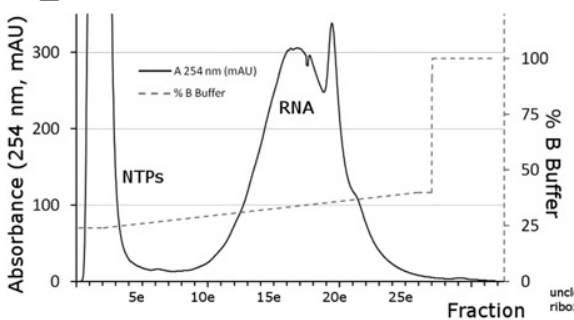

H
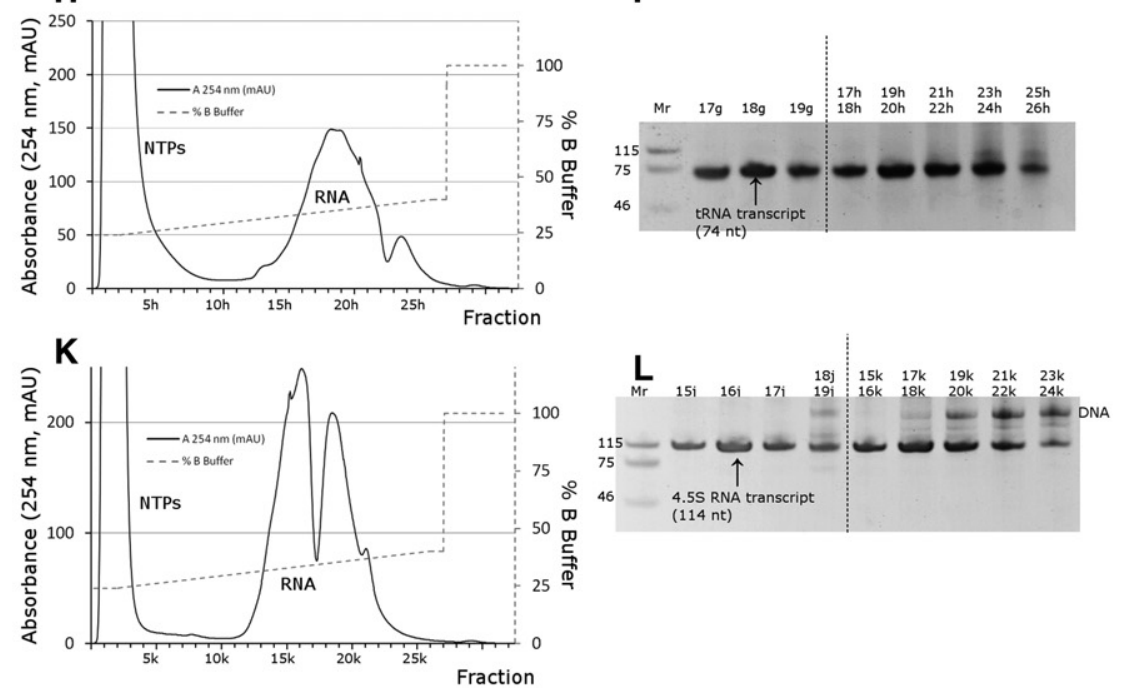

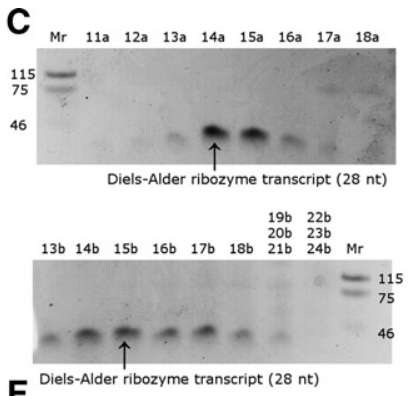

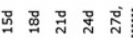

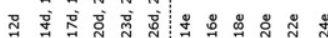

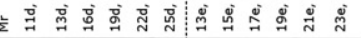

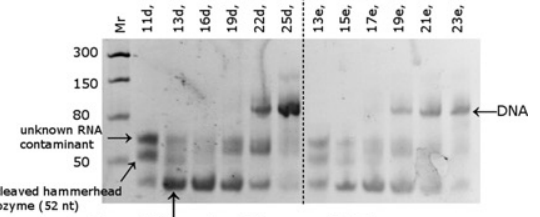

I

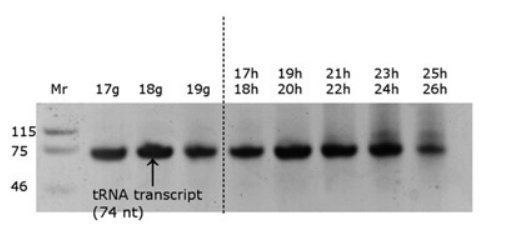

FIGURE 5. Purification of the transcription reactions of different transcripts on the Mono Q column or DEAE Sepharose and the subsequent fraction analysis on $12 \% \mathrm{NaOAc}$-urea PAGE. The transcripts of the Diels-Alder ribozyme (28 nt) are purified on Mono Q $(A)$ and DEAE Sepharose $(B)$. $(C)$ The eluted fractions are analyzed on PAGE. The hammerhead ribozyme transcript purification on the Mono Q column $(D)$ yields a complex chromatogram; however, a single broad peak $(E)$ on the DEAE Sepharose chromatogram suggests a loss of resolution for weak anion-exchange chromatography. $(F)$ The fraction analysis confirms better resolution of the Mono Q column. Similarly to the Diels-Alder ribozyme transcript, the purification of tRNA transcribed from the modified template $\left(2^{\prime}\right.$-O-nucleotides) on Mono Q $(G)$ or DEAE Sepharose $(H)$ does not show any difference on PAGE analysis $(I)$. The purification of the 4.5S RNA transcription reaction on the Mono Q column $(J)$ reveals a single peak, while on DEAE Sepharose $(K)$, this transcript is eluted as two distinct peaks. $(L)$ The electrophoresis reveals only the template and the 4.5S RNA transcript.

We have compared the resolving power directly with the DEAE Sepharose column of the same volume on different RNA transcripts. All tested transcripts show either better or similar resolution on the Mono Q column. Our results suggest that strong anion-exchange chromatography is superior to DEAE Sepharose in the separation of the RNA transcripts from the short oligonucleotide templates. However, the higher salt elution conditions of Mono Q FPLC do present certain disadvantages because these conditions may interfere with the RNA folding. All protocols are performed with only slight variations without the need for special buffer sys- tems, demonstrating the robustness of strong anion-exchange FPLC. The methods described and the findings derived from this study should be valuable for RNA production by in vitro transcription.

\section{MATERIALS AND METHODS}

\section{General}

We use strains E. coli DH5a and BL21 (DE3) for cloning, protein production, and a source of genomic material. Strains are cultured 
at $37^{\circ} \mathrm{C}$ on the standard LB agar plates or in the LB liquid medium with constant shaking (140 rpm). The oligonucleotides used in this work are all obtained from Genomics, the commercial enzymes and proteins are purchased from New England Biolabs, standard chemicals are obtained from Sigma-Aldrich, and the radioactive cysteine is purchased from PerkinElmer.

The Akta FPLC system is equipped with the strong anion binding Mono Q column 50/5 GL (GE) with a 1-mL column volume (CV) or HiTrap FF DEAE Sepharose with a 1-mL column volume. Buffer A in the FPLC system is composed of $20 \mathrm{mM}$ HEPES-KOH, $20 \mathrm{mM}$ $\mathrm{NaCl}$ ( $\mathrm{pH} 7.5$ ), and Buffer $\mathrm{B}$ is composed of $20 \mathrm{mM}$ HEPES$\mathrm{KOH}, 1.02 \mathrm{M} \mathrm{NaCl}$ ( $\mathrm{pH} 7.5$ ); both buffers are prepared from Diethylpyrocarbonate (DEPC)-treated water.

\section{Cloning and purification of pyrophosphatase}

The pyrophosphatase gene is amplified from genomic DNA of E. coli BL21 (DE3) using primers AGCTGTCATATGAGCTTAACTCAA CGTCCCTGCGGG and ATTCTCGAGTTAGTGGTGGTGGTGG TGGTGTTTATTCTTTGCGCGCTCGAAGGAGG to introduce the encoded His-tag to the $\mathrm{C}$ terminus of the protein and restriction sites $\mathrm{NdeI}$ and XhoI, which are used for a ligation into the pET21a vector. The construct is sequenced and transformed into the production strain, i.e., E. coli BL21 (DE3).

The cells are grown in $200 \mathrm{~mL}$ of LB medium with ampicillin (100 $\mu \mathrm{g} / \mathrm{mL}$ ) at $37^{\circ} \mathrm{C}$ to an O.D. $600 \mathrm{~nm}$ of 0.6 and are induced by $0.5 \mathrm{mM}$ IPTG. The induced cells are harvested after $2 \mathrm{~h}$ of additional incubation by centrifugation at $6000 \mathrm{~g}$ for $10 \mathrm{~min}$. Cell lysis is performed in a lysis buffer (20 mM HEPES, $250 \mathrm{mM} \mathrm{NaCl}$ at $\mathrm{pH} 7.5)$ by a French-press at 20,000 psi. The cell lysate is then separated into a supernatant and a pellet by centrifugation at $15,000 \mathrm{~g}$ for $30 \mathrm{~min}$.

The supernatant is applied to a Sepharose $\mathrm{Ni}^{2+}$ column $(3 \mathrm{~mL})$ preequilibrated with the lysis buffer, washed with $4 \times$ the column volume $(\mathrm{CV})$ of the lysis buffer with the addition of $10 \mathrm{mM}$ imidazole, $3 \times \mathrm{CV}$ of the lysis buffer with $50 \mathrm{mM}$ imidazole, and eluted with $3 \times \mathrm{CV}$ of the lysis buffer with 200 and $500 \mathrm{mM}$ imidazole.

The eluted protein is found mostly in the fractions eluted with 500 $\mathrm{mM}$ imidazole. The buffer is exchanged on a PD-10 column (GE) to $20 \mathrm{mM}$ HEPES, $20 \mathrm{mM} \mathrm{NaCl}$ ( $\mathrm{pH}$ 7.5), and the protein is concentrated using an Amicon ultracentrifugation column (MW cutoff $=3$ $\mathrm{kDa}$ ). The specific enzyme activity in $50 \mathrm{mM}$ Tris- $\mathrm{HCl}$ and $10 \mathrm{mM}$ $\mathrm{MgCl}_{2}$ ( $\mathrm{pH}$ 8.8) is determined using the malachite green assay (Baykov et al. 1988). The protein is incubated for $12 \mathrm{~h}$ at $37^{\circ} \mathrm{C}$ with $300 \mathrm{ng}$ of pET21a plasmid DNA and $1 \mu \mathrm{g}$ of small RNA (von Ehrenstein 1967) to determine DNase and RNase contaminations. After incubation, the DNA and RNA samples are resolved by $0.7 \%$ agarose electrophoresis for DNA and 3\% agarose electrophoresis for RNA; both types of gels are stained with SYBR Green.

The protein is applied onto a FPLC system equipped with the strong anion-exchange Mono Q column, preequilibrated with 20 mM HEPES, $0.12 \mathrm{M} \mathrm{NaCl}$ (pH 7.5) (10\% Buffer B) in two batches, each having $>0.5 \mathrm{~mL}$ (sample loop $0.5 \mathrm{~mL}$ ). The protein is resolved by a shallow linear gradient from $10 \%$ Buffer B to $50 \%$ Buffer B (20 mM HEPES, $0.52 \mathrm{M} \mathrm{NaCl}$ at $\mathrm{pH} 7.5$; gradient slope $16 \mathrm{mM} \mathrm{NaCl}$ per $\mathrm{CV}$ ) with a flow rate set to $1 \mathrm{~mL} / \mathrm{min}$ with continuous monitoring of the absorbance at $280 \mathrm{~nm}$; 1-mL fractions are collected.

The fractions are tested for a DNase contamination by incubating $9 \mu \mathrm{L}$ of each fraction with $300 \mathrm{ng}$ of pET21a DNA in a $10-\mu \mathrm{L}$ reaction with $10 \mathrm{mM} \mathrm{MgCl}_{2}$ for at least $12 \mathrm{~h}$ at $37^{\circ} \mathrm{C}$ and analyzed on the $0.7 \%$ agarose electrophoresis stained with SYBR Green.
The fractions with no detectable DNase contamination are tested for RNase contamination by incubation of $9 \mu \mathrm{L}$ of each fraction with $500 \mathrm{ng}$ of small RNA in a $10-\mu \mathrm{L}$ reaction with $10 \mathrm{mM} \mathrm{MgCl}_{2}$ for at least $12 \mathrm{~h}$ at $37^{\circ} \mathrm{C}$. The samples are analyzed on a $3 \%$ agarose gel stained with SYBR Green. The fractions with no detectable nuclease contamination are combined together and stored in $-20^{\circ} \mathrm{C}$ in 10 mM HEPES, $10 \mathrm{mM} \mathrm{NaCl}, 5 \mathrm{mM}$ DTT, and 50\% glycerol buffer ( $\mathrm{pH}$ 7.5). The pyrophosphatase activity is determined by the malachite green assay. To confirm the removal of nuclease contamination, the DNase and RNase assays are performed by incubating 10 units of the pyrophosphatase with $300 \mathrm{ng}$ of DNA and $500 \mathrm{ng}$ of small RNA using the same conditions as previously.

\section{Preparation of transcription templates}

The tRNA transcription templates are prepared from overlapping nucleotides using $2^{\prime}-O$-methyl nucleotides on the $5^{\prime}$ end of the complementary strand (Sherlin et al. 2001). Our E. coli tRNA transcription template was described previously (Hauenstein et al. 2004) (i.e., $5^{\prime}$ mUmGGAGGCGCGTTCCGGAGTCGAACCGGACTAGACGGA TTTGCAATCCGCTACAT and 5'-AATTCCTGCCGTAATACGA CTCACTATAGGCGCGTTAACAAAGCGG-TTATGTAGCGGA). The other template that does not contain the modified nucleotides is derived from the cysteine tRNA gene of $B$. subtilis (5'-TGGAGGCG ACACCCGGATTCGAACCGGGGATAAAGGTTTTGCAGACCTC TGCCTTA and 5'-AATTCCTGCCGTAATACGACTCACTATAGG CGGCATAGCCAAGTGGTA-AGGCAGAGGT). The same template is also used with the modified nucleotides on the $5^{\prime}$ end of the complementary strand (i.e., 5'-mUmGGAGGCGACACCC GGATTCGAACCGGGG-ATAAAGGTTTTGCAGACCTC-TGCC TTA) with the location of the T7 RNA polymerase promoter in bold and the overlapping part of each nucleotide underlined.

The screening of the optimal refilling conditions includes variations in the number of cycles and differences between cycle lengths. The temperature cycles are composed of changes between $37^{\circ} \mathrm{C}$ and $10^{\circ} \mathrm{C}$, with the cycle lengths between $30 \mathrm{sec}$ and $2 \mathrm{~min}$. The conditions are screened in $50-\mu \mathrm{L}$ reactions containing $200 \mathrm{pmol}$ of each oligonucleotide, $20 \mathrm{nmol}$ of each $\mathrm{dNTP}$, and 0.5 units of the Klenow fragment of DNA polymerase I. The volume is increased to $550 \mu \mathrm{L}$ with water, and the sample is applied on the Mono Q column preequilibrated with $20 \mathrm{mM}$ HEPES, $0.37 \mathrm{M} \mathrm{NaCl}$ ( $\mathrm{pH} 7.5$ ) (35\% of B Buffer). The sample is separated by a gradient from $35 \%$ to $80 \%$ B Buffer (20 mM HEPES, $0.82 \mathrm{M} \mathrm{NaCl}$ at $\mathrm{pH} 7.5$ ) over $15 \mathrm{CV}$ with a flow rate $1.25 \mathrm{~mL} / \mathrm{min}$, and the eluted samples are collected in 1-mL fractions; the absorbance was monitored at $254 \mathrm{~nm}$.

A large-scale preparation of the template is performed in a $500-\mu \mathrm{L}$ reaction containing $2 \mathrm{nmol}$ of each oligonucleotide, $200 \mathrm{nmol}$ of each dNTP, and 5 units of Klenow fragment. FPLC is performed as described previously.

The collected fractions containing either the unreacted oligonucleotides or the desired template product are precipitated, redissolved in $40 \mu \mathrm{L}$ of TE buffer $(10 \mathrm{mM}$ Tris, $1 \mathrm{mM}$ EDTA at $\mathrm{pH}$ 8.0 ), and analyzed by $3 \%$ agarose electrophoresis. The concentration is determined based on the absorption at $260 \mathrm{~nm}$ using a UV spectrophotometer. A $100-\mu \mathrm{L}$ reaction is purified by a PCR purification Kit (Viogene) used according to the manufacturer's instructions to compare the efficiency of this procedure.

The hammerhead ribozyme gene is prepared in a similar manner, using oligonucleotides 5'-AATTCCTGCCGTAATACGACTCACT 
ATAGGGAGACTGATGAGTCCGTGA and 5'-GGGAGAGACGG TACCGAGTACCGTTTCGTCCTCACGGACTCATC; the DielsAlder ribozyme gene is prepared by mixing oligonucleotides $5^{\prime}$ AATTCCTGCCGTAATACGACTCACTATAGGGCGAGGCCGTG CCAGCTCTTCGGAGC and 5'-GCTCCGAAGAGCTGGCAC GGCCTCGCCCTATAGTGAGTCGTATTACGGCAGGAATT. The 4.5S RNA gene is prepared using PCR from E. coli genomic DNA as a template using primers $\mathrm{ffs} F 5^{\prime}$-AATTCCTGCCGTAATAC GACTCACTATAGGGGGCTCTG-TTGGTTCTCCCG and ffs R 5 -GGGTGGGGGCCCTGCCAGC in a $200-\mu \mathrm{L}$ reaction that contains 40 pmol of each primer, $4 \mathrm{nmol}$ of dNTPs, $100 \mathrm{ng}$ of template DNA, and 2 units of Deep Vent Polymerase in the designated buffer. The temperature program of PCR is composed of $95^{\circ} \mathrm{C}$ for $5 \mathrm{~min}$, followed by $30 \mathrm{cycles}$ of $95^{\circ} \mathrm{C}$ for $45 \mathrm{sec}, 60^{\circ} \mathrm{C}$ for $45 \mathrm{sec}$, and $72^{\circ}$ $\mathrm{C}$ for $45 \mathrm{sec}$; the reaction is concluded with $5 \mathrm{~min}$ at $72^{\circ} \mathrm{C}$. The PCR products are purified by the PCR Purification Kit (Viogene) according to the manufacturer's instructions.

\section{Screening of transcription conditions}

Our standard transcription reaction is composed of $40 \mathrm{mM}$ Tris$\mathrm{HCl}$ ( $\mathrm{pH}$ 7.9), $2 \mathrm{mM}$ spermidine, $10 \mathrm{mM}$ dithiotrietol (DTT), 20 $\mathrm{mM} \mathrm{MgCl} 2,25$ units/mL pyrophosphatase, $1.6 \mathrm{mM}$ each rNTPs, $2.5 \mu \mathrm{g} / \mathrm{mL}$ single-strand binding protein (SSB), 1000 units $/ \mathrm{mL} \mathrm{T7}$ RNA polymerase, and $50 \mu \mathrm{g} / \mathrm{mL}$ template in a $20-\mu \mathrm{L}$ reaction.

The screening is composed of one variable component with the rest of the components fixed. The tested $\mathrm{MgCl}_{2}$ concentrations include $10 \mathrm{mM}, 15 \mathrm{mM}, 20 \mathrm{mM}, 30 \mathrm{mM}$, and $60 \mathrm{mM}$; for DTT, 10 $\mathrm{mM}, 15 \mathrm{mM}$, and $20 \mathrm{mM}$ are tested; pyrophosphatase is tested with the final activity 0 units $/ \mathrm{mL}, 25$ units $/ \mathrm{mL}$, and 75 units $/ \mathrm{mL}$; the rNTPs screening covers concentrations $0.4 \mathrm{mM}, 1.6 \mathrm{mM}, 3.2$ $\mathrm{mM}$, and $4.0 \mathrm{mM}$ final concentration, and the reaction is also checked in the presence or absence of SSB.

The reaction time is set to $12 \mathrm{~h}$, after which $530 \mu \mathrm{L}$ of water is added and the sample is applied onto the Mono Q column equilibrated with $20 \mathrm{mM}$ HEPES, $0.32 \mathrm{M} \mathrm{NaCl}$ (pH 7.5) (30\% of Buffer B; buffer system is not changed) followed by a linear gradient to a final $20 \mathrm{mM}$ HEPES, $0.82 \mathrm{M} \mathrm{NaCl}$ (pH 7.5) (80\% B Buffer) over $10 \mathrm{CV}$.

The results are evaluated by a comparison of the ratio between the area under the curve of the reaction products and the template.

\section{RNA transcription, purification, and analysis of products}

The transcription is usually performed in $500-\mu \mathrm{L}$ reactions, containing $40 \mathrm{mM}$ Tris- $\mathrm{HCl}, 10 \mathrm{mM} \mathrm{MgCl}, 10 \mathrm{mM}$ DTT, 25 units $/ \mathrm{mL}$ pyrophosphatase, $1.6 \mathrm{mM}$ each $\mathrm{rNTP}, 2.5 \mu \mathrm{g} / \mathrm{mL} \mathrm{SSB}, 30 \mu \mathrm{g} / \mathrm{mL}$ template, and 1000 units/mL T7 RNA polymerase for $12 \mathrm{~h}$ at $37^{\circ}$ C. This reaction mixture is directly applied to the preequilibrated Mono Q column and eluted by a linear $\mathrm{NaCl}$ gradient. The applied elution programs include linear gradients $0.02-1.02 \mathrm{M} \mathrm{NaCl}, 0.32$ $0.82 \mathrm{M} \mathrm{NaCl}$, and $0.46-0.62 \mathrm{M} \mathrm{NaCl}$. The absorbance is monitored at $254 \mathrm{~nm}$ and $1-\mathrm{mL}$ fractions are collected.

Alternatively, the transcripts are purified on a DEAE Sepharose column. The reactions are directly applied on the column equilibrated to $0.26 \mathrm{M} \mathrm{NaCl}$, the products are eluted by a linear gradient from 0.26 to $0.42 \mathrm{M} \mathrm{NaCl}$, and $1-\mathrm{mL}$ fractions are collected.

The transcription products are analyzed by $12 \%$ or $15 \% \mathrm{NaOAc}$ urea PAGE (0.15 M NaOAc, $7 \mathrm{M}$ urea at $\mathrm{pH}$ 5.5) (Varshney et al.
1991), 12\% TBE-urea PAGE ( $89 \mathrm{mM}$ Tris, $89 \mathrm{mM}$ Borate, $1 \mathrm{mM}$ EDTA, $7 \mathrm{M}$ urea at $\mathrm{pH} 8.3$ ), and on a $2 \%$ TBE agarose gel. Nucleic acids are stained with SYBR Green. The identity of the peak with the template DNA is confirmed by incubation with 0.25 units of DNase I for $10 \mathrm{~min}$ at $37^{\circ} \mathrm{C}$. The aminoacylation assays are performed according to Francklyn et al. (2008) using ${ }^{35}$ S-cysteine as the labeled substrate. The aminoacylation yield is calculated as a ratio of the incorporated 35S-cysteine per absorption unit, considering 1600 pmol of $35 \mathrm{~S}$ cysteine per $1 \mathrm{AU}$ as $100 \%$ incorporation yield.

\section{ACKNOWLEDGMENTS}

We thank Professor Sunney I. Chan and Tiow-Gan Ong from Academia Sinica for the valuable comments and revision in this manuscript. This work was supported by research grants from The National Science Council of the Republic of China and Academia Sinica (Grants NSC 98-2113-M-001-015-MY2, NSC 100-2113-M001-013-MY2, NSC 101-2113-M-002-006-MY2, and AS99-TP-AB5).

Received January 3, 2013; accepted June 25, 2013.

\section{REFERENCES}

Anderson AC, Scaringe SA, Earp BE, Frederick CA. 1996. HPLC purification of RNA for crystallography and NMR. RNA 2: 110-117.

Avis JM, Conn GL, Walker SC. 2012. Cis-acting ribozymes for the production of RNA in vitro transcripts with defined $5^{\prime}$ and $3^{\prime}$ ends. Methods Mol Biol 941: 83-98.

Batey RT, Kieft JS. 2007. Improved native affinity purification of RNA. RNA 13: 1384-1389.

Baykov AA, Evtushenko OA, Avaeva SM. 1988. A malachite green procedure for orthophosphate determination and its use in alkaline phosphatase-based enzyme immunoassay. Anal Biochem 171: 266270.

Cech TR, Bass BL. 1986. Biological catalysis by RNA. Annu Rev Biochem 55: 599-629.

Di Tomasso G, Lampron P, Dagenais P, Omichinski JG, Legault P. 2011. The ARiBo tag: A reliable tool for affinity purification of RNAs under native conditions. Nucleic Acids Res 39: e18.

Easton LE, Shibata Y, Lukavsky PJ. 2010. Rapid, nondenaturing RNA purification using weak anion-exchange fast performance liquid chromatography. RNA 16: 647-653.

Ferré-D'Amaré AR, Doudna JA. 1996. Use of cis- and trans-ribozymes to remove $5^{\prime}$ and $3^{\prime}$ heterogeneities from milligrams of in vitro transcribed RNA. Nucleic Acids Res 24: 977-978.

Flanagan JJ, Chen JC, Miao Y, Shao Y, Lin J, Bock PE, Johnson AE. 2003. Signal recognition particle binds to ribosome-bound signal sequences with fluorescence-detected subnanomolar affinity that does not diminish as the nascent chain lengthens. J Biol Chem 278: 1862818637.

Francklyn CS, First EA, Perona JJ, Hou YM. 2008. Methods for kinetic and thermodynamic analysis of aminoacyl-tRNA synthetases. Methods 44: 100-118.

Gu SQ, Jöckel J, Beinker P, Warnecke J, Semenkov YP, Rodnina MV, Wintermeyer W. 2005. Conformation of 4.5S RNA in the signal recognition particle and on the $30 \mathrm{~S}$ ribosomal subunit. RNA 11: $1374-1384$.

Gubbens J, Kim SJ, Yang Z, Johnson AE, Skach WR. 2010. In vitro incorporation of nonnatural amino acids into protein using tRNA ${ }^{\mathrm{Cys}}$ derived opal, ochre, and amber suppressor tRNAs. RNA 16: 16601672 .

Hauenstein S, Zhang CM, Hou YM, Perona JJ. 2004. Shape-selective RNA recognition by cysteinyl-tRNA synthetase. Nat Struct Mol Biol 11: 1134-1141. 
He B, Rong M, Lyakhov D, Gartenstein H, Diaz G, Castagna R, McAllister WT, Durbin RK. 1997. Rapid mutagenesis and purification of phage RNA polymerases. Protein Expr Purif 9: 142-151.

Hou Y, Schimmel P. 1988. A simple structural feature is a major determinant of the identity of a transfer-RNA. Nature 333: 140-145.

Hou YM, Westhof E, Giegé R. 1993. An unusual RNA tertiary interaction has a role for the specific aminoacylation of a transfer RNA. Proc Natl Acad Sci 90: 6776-6780.

Jahn MJ, Jahn D, Kumar AM, Söll D. 1991. Mono Q chromatography permits recycling of DNA template and purification of RNA transcripts after T7 RNA polymerase reaction. Nucleic Acids Res 19: 2786.

Kao C, Zheng M, Rüdisser S. 1999. A simple and efficient method to reduce nontemplated nucleotide addition at the $3^{\prime}$ terminus of RNAs transcribed by T7 RNA polymerase. RNA 5: 1268-1272.

Keel AY, Easton LE, Lukavsky PJ, Kieft JS. 2009. Large-scale native preparation of in vitro transcribed RNA. Methods Enzymol 469: 3-25.

Kieft JS, Batey RT. 2004. A general method for rapid and nondenaturing purification of RNAs. RNA 10: 988-995.

Kim I, McKenna SA, Viani Puglisi E, Puglisi JD. 2007. Rapid purification of RNAs using fast performance liquid chromatography (FPLC). RNA 13: 289-294.

Lilley DM. 2003. The origins of RNA catalysis in ribozymes. Trends Biochem Sci 28: 495-501.

Lin KF, Sun CS, Huang YC, Chan SI, Koubek J, Wu TH, Huang JJ. 2012. Cotranslational protein folding within the ribosome tunnel influences trigger-factor recruitment. Biophys J 102: 2818-2827.

Lukavsky PJ, Puglisi JD. 2004. Large-scale preparation and purification of polyacrylamide-free RNA oligonucleotides. RNA 10: 889-893.

McKenna SA, Kim I, Puglisi EV, Lindhout DA, Aitken CE, Marshall RA, Puglisi JD. 2007. Purification and characterization of transcribed RNAs using gel filtration chromatography. Nat Protoc 2: 32703277.

Perona JJ, Swanson R, Steitz TA, Söll D. 1988. Overproduction and purification of Escherichia coli tRNA(2Gln) and its use in crystallization of the glutaminyl-tRNA synthetase-tRNA(Gln) complex. J Mol Biol 202: $121-126$.
Pikovskaya O, Serganov AA, Polonskaia A, Serganov A, Patel DJ. 2009. Preparation and crystallization of riboswitch-ligand complexes. Methods Mol Biol 540: 115-128.

Ponchon L, Dardel F. 2011. Large scale expression and purification of recombinant RNA in Escherichia coli. Methods 54: 267-273.

Price SR, Ito N, Oubridge C, Avis JM, Nagai K. 1995. Crystallization of RNA-protein complexes. I. Methods for the large-scale preparation of RNA suitable for crystallographic studies. J Mol Biol 249: 398-408.

Rodríguez-Hernández A, Perona JJ. 2011. Heat maps for intramolecular communication in an RNP enzyme encoding glutamine. Structure 19: $386-396$.

Romanovskaya A, Sarin LP, Bamford DH, Poranen MM. 2013. Highthroughput purification of double-stranded RNA molecules using convective interaction media monolithic anion exchange columns. J Chromatogr A 1278: 54-60.

Rupert PB, Ferré-D'Amaré AR. 2004. Crystallization of the hairpin ribozyme: Illustrative protocols. Methods Mol Biol 252: 303-311.

Seelig B, Jäschke A. 1999. A small catalytic RNA motif with DielsAlderase activity. Chem Biol 6: 167-176.

Sherlin LD, Bullock TL, Nissan TA, Perona JJ, Lariviere FJ, Uhlenbeck OC, Scaringe SA. 2001. Chemical and enzymatic synthesis of tRNAs for high-throughput crystallization. RNA 7: 1671-1678.

Shields TP, Mollova E, Ste Marie L, Hansen MR, Pardi A. 1999. Highperformance liquid chromatography purification of homogenouslength RNA produced by trans cleavage with a hammerhead ribozyme. RNA 5: 1259-1267.

Uhlenbeck O. 1995. Keeping RNA happy. RNA 1: 4-6.

Varshney U, Lee CP, RajBhandary UL. 1991. Direct analysis of aminoacylation levels of tRNAs in vivo. Application to studying recognition of Escherichia coli initiator tRNA mutants by glutaminyl-tRNA synthetase. J Biol Chem 266: 24712-24718.

von Ehrenstein G. 1967. Isolation of sRNA from intact Escherichia coli cells. Methods Enzymol 12, Part A: 588-596.

Wyatt JR, Chastain M, Puglisi JD. 1991. Synthesis and purification of large amounts of RNA oligonucleotides. BioTechniques 11: 764-769. 

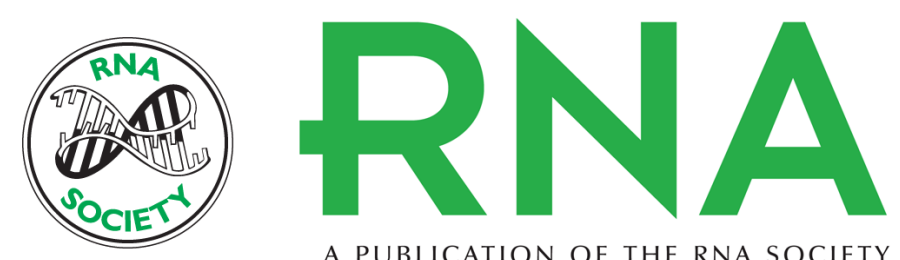

A PUBLICATION OF THE RNA SOCIETY

\section{Strong anion-exchange fast performance liquid chromatography as a versatile tool for preparation and purification of RNA produced by in vitro transcription}

Jiri Koubek, Ku Feng Lin, Yet Ran Chen, et al.

RNA 2013 19: 1449-1459 originally published online August 8, 2013

Access the most recent version at doi:10.1261/rna.038117.113

References This article cites 39 articles, 14 of which can be accessed free at:

http://rnajournal.cshlp.org/content/19/10/1449.full.html\#ref-list-1

Creative This article is distributed exclusively by the RNA Society for the first 12 months after the

Commons full-issue publication date (see http://rnajournal.cshlp.org/site/misc/terms.xhtml). After 12

License months, it is available under a Creative Commons License (Attribution-NonCommercial 3.0 Unported), as described at http://creativecommons.org/licenses/by-nc/3.0/.

Email Alerting Receive free email alerts when new articles cite this article - sign up in the box at the Service top right corner of the article or click here.

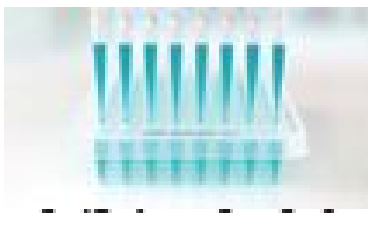

Providing Precise Solutions for your research.

To subscribe to RNA go to:

http://rnajournal.cshlp.org/subscriptions

(C) 2013; Published by Cold Spring Harbor Laboratory Press for the RNA Society 